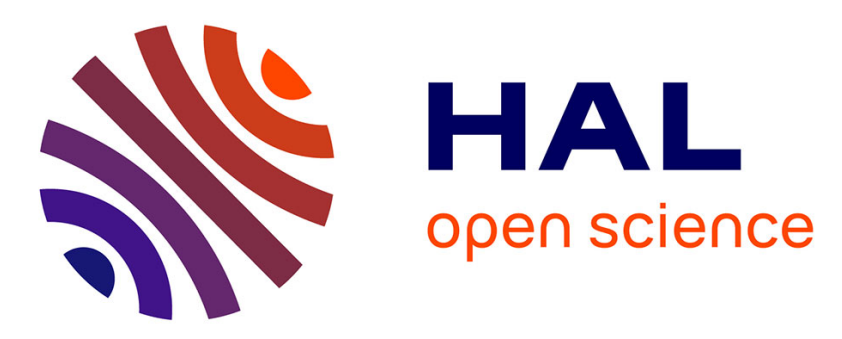

\title{
The $\mathrm{HO}$ and $\mathrm{CO}$ adsorption properties of phyllosilicate-poor palagonitic dust and smectites under martian environmental conditions
}

\author{
Jochen Jänchen, Richard V. Morris, David L. Bish, Mareike Janssen, Udo
}

Hellwig

\section{To cite this version:}

Jochen Jänchen, Richard V. Morris, David L. Bish, Mareike Janssen, Udo Hellwig. The HO and CO adsorption properties of phyllosilicate-poor palagonitic dust and smectites under martian environmental conditions. Icarus, 2009, 200 (2), pp.463. 10.1016/j.icarus.2008.12.006 . hal-00517245

\author{
HAL Id: hal-00517245 \\ https://hal.science/hal-00517245
}

Submitted on 14 Sep 2010

HAL is a multi-disciplinary open access archive for the deposit and dissemination of scientific research documents, whether they are published or not. The documents may come from teaching and research institutions in France or abroad, or from public or private research centers.
L'archive ouverte pluridisciplinaire HAL, est destinée au dépôt et à la diffusion de documents scientifiques de niveau recherche, publiés ou non, émanant des établissements d'enseignement et de recherche français ou étrangers, des laboratoires publics ou privés. 


\section{Accepted Manuscript}

The $\mathrm{H}_{2} \mathrm{O}$ and $\mathrm{CO}_{2}$ adsorption properties of phyllosilicate-poor palagonitic dust and smectites under martian environmental conditions

Jochen Jänchen, Richard V. Morris, David L. Bish, Mareike Janssen, Udo Hellwig

PII: $\quad$ S0019-1035(08)00430-2

DOI: $\quad$ 10.1016/j.icarus.2008.12.006

Reference: $\quad$ YICAR 8840

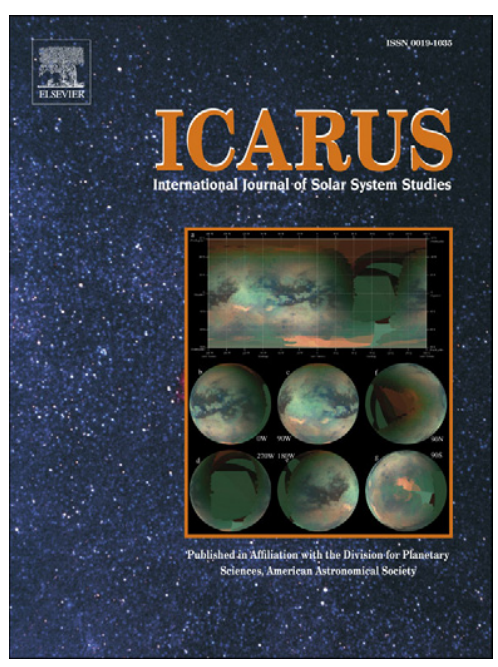

To appear in: Icarus

Received date: 3 December 2007

Revised date: 15 September 2008

Accepted date: 2 December 2008

Please cite this article as: J. Jänchen, R.V. Morris, D.L. Bish, M. Janssen, U. Hellwig, The $\mathrm{H}_{2} \mathrm{O}$ and $\mathrm{CO}_{2}$ adsorption properties of phyllosilicate-poor palagonitic dust and smectites under martian environmental conditions, Icarus (2009), doi: 10.1016/j.icarus.2008.12.006

This is a PDF file of an unedited manuscript that has been accepted for publication. As a service to our customers we are providing this early version of the manuscript. The manuscript will undergo copyediting, typesetting, and review of the resulting proof before it is published in its final form. Please note that during the production process errors may be discovered which could affect the content, and all legal disclaimers that apply to the journal pertain. 
The $\mathrm{H}_{2} \mathrm{O}$ and $\mathrm{CO}_{2}$ adsorption properties of phyllosilicate-poor palagonitic dust and smectites under martian environmental conditions

Jochen Jänchen ${ }^{\mathrm{a}}$, Richard V. Morris ${ }^{\mathrm{b}}$, David L. Bish ${ }^{\mathrm{c}}$, Mareike Janssen ${ }^{\mathrm{a}}$, Udo Hellwiga .

${ }^{\mathrm{a}}$ TFH Wildau (University Applied Sciences), Bahnhofstraße, 15745 Wildau, Germany.

${ }^{\mathrm{b}}$ NASA Johnson Space Center, 2101 NASA Parkway, Houston, TX 77058 USA.

${ }^{\mathrm{c}}$ Indiana University, $1001 \mathrm{E} 10^{\text {th }}$ St., Bloomington, IN 47405 USA.

Pages: 21

Tables: 1

Figures: 8 
Proposed Running Head: $\mathrm{H}_{2} \mathrm{O}$ sorption properties of Mars dust analog

\section{Editorial correspondence to:}

Dr. Jochen Jänchen

TFH Wildau,

c/o ZeoSolar e.V.

Volmerstr. 13

D-12489 Berlin, Germany

Phone: +49 3063922574

Fax: $\quad+493063922574$

E-mail address: j.e.jaenchen@t-online.de

\section{ABSTRACT}

The recent detection of up to $\sim 10 \mathrm{wt} . \%$ water-equivalent $\mathrm{H}$ heterogeneously distributed in the upper meter of the equatorial regions of the martian surface and the presence of the $3-\mu \mathrm{m}$ hydrations feature across the entire planet raises the question whether martian surficial dust can account for this water-equivalent $\mathrm{H}$. We have investigated the $\mathrm{H}_{2} \mathrm{O}$ and $\mathrm{CO}_{2}$ adsorption properties of palagonitic dust $(<5 \mu \mathrm{m}$ size fraction of phyllosilicate-poor palagonitic tephra HWMK919) as a martian dust analog and two smectites under simulated martian equatorial surface conditions. Our results show that the palagonitic dust, which contains hydrated and hydroxylated volcanic glass of basaltic composition, accommodates significantly more $\mathrm{H}_{2} \mathrm{O}$ under comparable humidity and temperature conditions than do the smectites nontronite and montmorillonite.

Key Words: Mars, surface; mineralogy; geochemistry; palagonite; smectite; water, adsorption 


\section{Introduction}

Palagonitic tephras (basaltic tephra containing hydrated and hydroxylated volcanic glass of basaltic composition) have received widespread attention in the planetary literature because many are basaltic spectral and magnetic analogs of bright martian surface materials (e.g., Morris et al. 2000, 2001). Here we report the $\mathrm{H}_{2} \mathrm{O}$ and $\mathrm{CO}_{2}$ adsorption properties for the $<5$ $\mu \mathrm{m}$ size fraction of phyllosilicate-poor palagonitic HWMK919 from the Island of Hawaii under simulated martian conditions. This size fraction was chosen because it is a size analog for martian dust, which has a mean diameter of $3.4 \pm 0.6 \mu \mathrm{m}$ and $3.0 \pm 0.4 \mu \mathrm{m}$ from measurements made by Mars Pathfinder and the Mars Exploration Rovers, respectively (Markiewicz et al., 1999; Lemmon et al., 2004). For comparison, we acquired equivalent data for two smectites (nontronite and montmorillonite) which have been spectroscopically identified on Mars by visible-near-infrared instruments on orbiting spacecraft (Bibring et al. 2005; Poulet et al. 2005; Mustard et al. 2008). Although these smectites are localized in Noachian bedrock terrains, and do not appear to be important components of the martian dust, their $\mathrm{H}_{2} \mathrm{O}$ contents under martian surface conditions can be on the order of $2-8 \mathrm{wt} \%$ (Bish et al., 2003; Jänchen et al., 2006) and they have been suggested as possible hosts for $\mathrm{H}_{2} \mathrm{O}$ on the martian surface.

Our results are important for and focus on understanding the speciation (e.g., $\mathrm{H}_{2} \mathrm{O}$ ice, adsorbed $\mathrm{H}_{2} \mathrm{O}$, and hydrated and hydroxylated phases) of up to $\sim 10 \mathrm{wt} \% \mathrm{H}_{2} \mathrm{O}$-equivalent $\mathrm{H}$ in the upper meter of the near-equatorial martian surface as detected by the gamma-ray and neutron spectrometer instruments on Mars Odyssey (Feldman et al. 2004; Boynton et al. 2004). The presence of the 3- $\mu \mathrm{m}$ hydration feature across the entire planet as detected by OMEGA (Jouglet et al., 2007; Milliken et al., 2007) could also result from martian dust, if the dust contains a component that is able to accommodate sufficient $\mathrm{H}_{2} \mathrm{O}$ and satisfy spectroscopic constraints under martian environmental conditions. 
This paper builds on previous published work on the interaction of Martian atmospheric $\mathrm{H}_{2} \mathrm{O}$ and $\mathrm{CO}_{2}$ with Mars analog samples under simulated Martian environmental conditions (e.g., Fanale and Cannon, 1978; Yen et al., 1998; Bish et al., 2003; Zent et al., 1987, 1997, 2001).

\section{Experimental}

The samples selected for this comparative adsorption study were a palagonitic tephra and two smectites. The palagonitic dust sample is the $<5 \mu \mathrm{m}$ size fraction of palagonitic tephra HWMK919 from Mauna Kea Volcano, Hawaii is phyllosilicate-poor (Morris et al., 2001) and served as a size analog for martian dust. The sample does contain plagioclase, pyroxene, magnetite, and allophane (an $\mathrm{H}_{2} \mathrm{O} / \mathrm{OH}$ bearing phase) according to powder X-ray diffraction. The primary Fe-bearing phase is nanophase ferric oxide (potentially an $\mathrm{H}_{2} \mathrm{O} / \mathrm{OH}$-bearing phase by analogy with ferrihydrite) according to Mössbauer measurements. Although Morris et al. (2001) show that HWMK919 contains less than 3\% smectite (the detection limit), we refer to this sample as phyllosilicate poor rather than phyllosilicate free, for clarity. The smectite samples are Ca-montmorillonite (Clay Minerals Society Source Clay STx-1, Gonzales County, Texas, USA) and nontronite (NG-1, Hoher Hagen, Darnsfeld, Göttingen, Germany). Scanning electron microscopy (SEM, JEOL JSM640), and X-ray powder diffraction (Bruker D8, Cu Ka radiation) were applied to characterize the solids.

$\mathrm{H}_{2} \mathrm{O}$ adsorption and desorption isotherms were measured gravimetrically from 255 to 313 $\mathrm{K}$ at $10^{-4}$ to $10 \mathrm{mbar}$ with a McBain quartz spring balance (sensitivity $4 \mathrm{mg} / \mathrm{mm}$, resolution $10^{-}$ ${ }^{2} \mathrm{~mm}$ ) equipped with MKS Baratron pressure heads of high sensitivity in the range $10^{-5}$ to $10^{3}$ mbar. The error of the isotherm measurements corresponds to $2.5-4 \%$ related to the adsorbed amount, a, in $\mathrm{g} / \mathrm{g}$ adsorbent. $\mathrm{CO}_{2}$ adsorption and desorption isotherms were determined volumetrically from 196 to $293 \mathrm{~K}$ and from 0.1 to 1000 mbar using a Quantachrome Autosorb-1 instrument. This instrument was also used for the standard $\mathrm{N}_{2}$ BET surface area 
and isotherm measurements at $77 \mathrm{~K}$. The micropore analysis (micropore volume) of the samples was carried out by applying the t-method (De Boer et al., 1965) using the $\mathrm{N}_{2}$ isotherms. This technique involves the same $\mathrm{N}_{2}$ isotherm measurements as that employed in the BET method, but extended to some what higher pressure values. The t-plot is a plot of the volume of gas adsorbed versus $t$, the statistical thickness of the adsorbed film. The $t$ values are a function of the relative pressure and can be calculated by equations of De Boer. Differences in slope of the t-plot between the micropore- and mesopore adsorption region of the material allow to distinguish between the corresponding surface area and pore volume values of that porous material.

Before each $\mathrm{H}_{2} \mathrm{O}-, \mathrm{CO}_{2^{-}}$and $\mathrm{N}_{2}$-adsorption experiment, about $150 \mathrm{mg}$ of sample was degassed at $383 \mathrm{~K}$ and $\mathrm{p}<10^{-5}$ mbar for several hours. Under these conditions, however, not all strongly adsorbed or structural $\mathrm{H}_{2} \mathrm{O}$ was removed (especially for HWMK919, which retained about one third of the total $\mathrm{H}_{2} \mathrm{O}$ compared with the total mass loss). For these measurements we did not heat the samples to higher temperatures because low degassing temperatures are crucial to prevent possible modifications to the solids. To evaluate the impact of heating on the properties of HWMK919 we also measured the $\mathrm{N}_{2}$ BET surface area and the $\mathrm{CO}_{2}$ adsorption isotherms after heating at $623 \mathrm{~K}$.

$\mathrm{Hg}$ intrusion measurements were carried out with the Pascal 140 and 440 instrument in a pressure range of $0-400 \mathrm{MPa}$ to obtain information on the particle size distribution (Mayer and Stowe method was used). The samples were evacuated for 15 minutes before the measurements.

Thermogravimetry (TG) was performed on a SETARAM TG-DSC 111 apparatus with a heating rate of $3 \mathrm{~K} / \mathrm{min}$ from ambient to $723 \mathrm{~K}$. Samples of about $12-14 \mathrm{mg}$ were equilibrated at room temperature in a desiccator for about two weeks at $\mathrm{p} / \mathrm{p}_{0}\left(\mathrm{H}_{2} \mathrm{O}\right)$ of 0.3 prior to the TG experiments. The TG and $\mathrm{N}_{2}$ isotherm measurements were repeated twice and the $\mathrm{CO}_{2}$ isotherms were repeated once showing high reproducibility of the measurements. 


\section{Results and Discussion}

The gas adsorption behavior of porous materials is determined by the energetic properties of adsorption sites, by specific surface area, by pore size distribution, and pore volume. The values of specific surface area, pore diameter, and micropore volume (average of triplicat measurements), average particle diameter, and mass loss after equilibration at $\mathrm{H}_{2} \mathrm{O} p / \mathrm{p}_{0}=0.3$ are given in Table 1 for the palagonitic dust and smectites.

\section{[Table 1, Figure 1]}

The HWMK919 palagonitic dust has a significantly higher surface area than the smectites and has pores $<2 \mathrm{~nm}$ in diameter (micropores) in addition to some mesopores $(\sim 4 \mathrm{~nm}$ diameter). The smectites have small $\mathrm{N}_{2}$ BET surface areas and only mesopores because $\mathrm{N}_{2}$, as opposed to $\mathrm{H}_{2} \mathrm{O}$, is unable to penetrate into the interlayer spaces of the smectites. All data in Table 1, column 2-4 were derived from the $\mathrm{N}_{2}$ adsorption isotherms (Figure 1). The shape and position of the isotherms in the diagram illustrate the difference in the two types of samples. Low $\mathrm{N}_{2}$ uptake at low relative pressures for the smectites indicates the absence of micropores for $\mathrm{N}_{2}$, and the pronounced adsorption hysteresis for $\mathrm{p} / \mathrm{p}_{0}>0.4$ is very characteristic of capillary condensation in mesopores. Much higher uptake at low $\mathrm{p} / \mathrm{p}_{0}$ and the less pronounced hysteresis loop for the phyllosilicate-poor palagonitic dust in Figure 1 indicate the presence of significantly smaller pores compared to the smectites. Because the particle diameter for the three samples is comparable (Table 1), the particle diameter cannot control the difference in adsorption properties between the palagonitic dust and the two smectites. Figure 2 shows an SEM image for the palagonitic dust that confirms the particle size distribution of $<5 \mu \mathrm{m}$ reported by Morris et al. (2001). Column 6 of Table 1 summarizes the total mass loss of the samples (means of three different measurements) determined by TG between 293 and $673 \mathrm{~K}$ after equilibration at a water vapour pressure of $\mathrm{p} / \mathrm{p}_{0}=0.3$. HWMK919 shows by far the largest mass loss. 


\section{[Figure 2]}

The results of the TG measurements are illustrated in more detail in Figures 3 and 4. The HWMK919 palagonitic dust accommodated significantly more $\mathrm{H}_{2} \mathrm{O}$ than the two other samples if the total mass loss of $0.325 \mathrm{~g} / \mathrm{g}$ is assigned to $\mathrm{H}_{2} \mathrm{O}$. Desorption of a considerable amount of this $\mathrm{H}_{2} \mathrm{O}$ (i.e., insignificant dehydroxylation) is consistent with the high BET surface area of this sample which is in fact $>203 \mathrm{~m}^{2} / \mathrm{g}$ if the dry mass would be corrected by subtracting the residual $\mathrm{H}_{2} \mathrm{O}$ remaining in the sample after degassing at $383 \mathrm{~K}$. Samples NG-1 and STx-1 lost most of their $\mathrm{H}_{2} \mathrm{O}$ below $383 \mathrm{~K}$ upon heating (Figures 3 and 4), whereas HWMK919 lost only half of the $\mathrm{H}_{2} \mathrm{O}$ from its pore system up to $383 \mathrm{~K}$. The derivative TG (DTG) pattern of HWMK919 in Figure 4 confirms the differences from the two other samples and illustrates the more strongly bonded $\mathrm{H}_{2} \mathrm{O}$ associated with this sample. Based on these data, we expect that HWMK919 palagonitic dust has the potential to hold more $\mathrm{H}_{2} \mathrm{O}$ under martian environmental conditions than do smectites, a somewhat unexpected result.

\section{[Figure 3, Figure 4]}

Figure 5 shows the $\mathrm{H}_{2} \mathrm{O}$ adsorption isotherms for HWMK919 palagonitic dust at temperatures between 255 and $313 \mathrm{~K}$. The isotherms become steep approaching the corresponding condensation pressure of $\mathrm{H}_{2} \mathrm{O}$ (e.g., 1.1 mbar at $255 \mathrm{~K}, 6.1 \mathrm{mbar}$ at $273 \mathrm{~K}$, and 23 mbar at $293 \mathrm{~K}$ ). This behavior indicates unlimited multilayer adsorption between aggregates of small particles or in large pores at high relative pressures as seen also with nitrogen adsorption (Figure 1). The $\mathrm{H}_{2} \mathrm{O}$ uptake measured at 0.001 mbar (martian surface pressure of water vapor; dashed line in Figure 5) amounts to $2.5 \mathrm{wt} \%(0.025 \mathrm{~g} / \mathrm{g})$ at $255 \mathrm{~K}$ and is significantly higher than the amounts observed by Zent and Quinn (1997). It should be mentioned that the adsorption and desorption of $\mathrm{H}_{2} \mathrm{O}$ in HWMK919 is a slow process and therefore an equilibration time of $12 \mathrm{~h}$ between data points (dosing) in the isotherms was used. The slow adsorption/desorption kinetics will be important in determining whether or not 
phyllosilicate-poor palagonite can be considered to be important in affecting the diurnal martian atmospheric $\mathrm{H}_{2} \mathrm{O}$ cycle, and the slow kinetics suggest that it will not.

\section{[Figure 5, Figure 6]}

Figure 6 compares the $\mathrm{H}_{2} \mathrm{O}$ adsorption isotherms for HWMK919 with those for NG-1 at $293 \mathrm{~K}$. The maximum uptake of $\mathrm{H}_{2} \mathrm{O}$ up to 10 mbar appears to be the same for both materials, although HWMK919 adsorbed more $\mathrm{H}_{2} \mathrm{O}$ at significantly lower $\mathrm{p}\left(\mathrm{H}_{2} \mathrm{O}\right)$ compared with $\mathrm{NG}-1$ (and also STx-1; cf. Jänchen et al., 2006). Moreover, HWMK919 retained about 0.1 g/g "extra" $\mathrm{H}_{2} \mathrm{O}$ after the degassing procedure prior to the isotherm measurements and $\mathrm{NG}-1$ retained much less (cf., results of the TG measurements).

$\mathrm{CO}_{2}$ adsorption measurements gave results similar to those for $\mathrm{H}_{2} \mathrm{O}$ adsorption (Figures 7 and 8), although the hysteresis obvious in Figures 5 and 6 was not seen with $\mathrm{CO}_{2}$ adsorption, and in contrast to the results of Zent (1986), was reversible for $\mathrm{CO}_{2}$. The hysteresis observed for $\mathrm{H}_{2} \mathrm{O}$ adsorption on HWMK919 appears to be a kinetic effect (Figure 6; filled triangles shift towards adsorption branch within 30 days). However, this was not the case for smectites (NG-1 in Figure 6), which exhibited marked hysteresis resulting from structural phase transitions involving interlayer $\mathrm{H}_{2} \mathrm{O}$ that are obvious in controlled-humidity X-ray diffraction data (e.g., Chipera et al., 1997).

\section{[Figure 7, Figure 8]}

The $\mathrm{CO}_{2}$ adsorption isotherms for HWMK919 palagonitic dust measured at 196-293 K (Figure 7) plotted in an a vs. $\log (\mathrm{p})$ diagram give the adsorbed amount, a, in $\mathrm{g}^{\mathrm{CO}_{2} / \mathrm{g}}$ adsorbent as function of the $\mathrm{CO}_{2}$ pressure on a logarithmic scale. Figure 7 shows that a considerable amount $(\sim 0.04 \mathrm{~g} / \mathrm{g})$ of $\mathrm{CO}_{2}$ can be adsorbed at $196 \mathrm{~K}$ and 6 mbar, the $\mathrm{CO}_{2}$ surface pressure on Mars. However, this amount of adsorption occurs only in the absence of $\mathrm{H}_{2} \mathrm{O}$ vapor. It has been demonstrated (Jänchen et. al, 2007) that for energetic reasons $\mathrm{H}_{2} \mathrm{O}$ is preferred over $\mathrm{CO}_{2}$, even at a surplus of $\mathrm{CO}_{2}$ as is the case for the atmosphere on the martian surface. Figure 8 compares the $\mathrm{CO}_{2}$ isotherms for HWMK919 with those for NG-1, 
illustrating that HWMK919 has a higher affinity for polar molecules (including $\mathrm{CO}_{2}$ ) than do the smectites (again because $\mathrm{CO}_{2}$ might not be able to penetrate into the smectite interlayer regions).

The reason for the high affinity of HWMK919 for $\mathrm{H}_{2} \mathrm{O}$ may have to do not only with the pore structure (very small pores) but also with the chemical composition and the surface functional groups on the solids in this material. The $<5 \mu \mathrm{m}$ fraction of HWMK919 contains a large amount of allophane which may contribute to the high level of $\mathrm{H}_{2} \mathrm{O}$ adsorption at low partial pressures, possibly because of the presence of surface hydroxyl species (Hamayoon et al., 2006) such as $\mathrm{Al}(\mathrm{OH}) \mathrm{Al}, \mathrm{Si}(\mathrm{OH}), \mathrm{Al}(\mathrm{OH})_{2}, \mathrm{Si}(\mathrm{OH})_{2}$ and $\mathrm{Al}(\mathrm{OH}) \mathrm{Si}$, all of which are known as strong specific adsorption sites for $\mathrm{H}_{2} \mathrm{O}$.

The strongly bonded $\mathrm{H}_{2} \mathrm{O}$ on specific sites (and possibly some structural water) account for the weight losses that occurred for HWMK919 at high temperatures in TG experiments (Figures 3 and 4). This $\mathrm{H}_{2} \mathrm{O}$ loss is not completely reversible because it changes the structure of the sample. Our experiments with HWMK919 degassed at $623 \mathrm{~K}$ instead of $383 \mathrm{~K}$ show a significant decrease in the specific surface area (from $>203$ to $185 \mathrm{~m}^{2} / \mathrm{g}$ ), and the $\mathrm{CO}_{2}$ adsorption isotherms indicate a diminished uptake by about $35 \%$, demonstrating the occurrence of irreversible structural changes in HWMK919 at elevated temperatures.

Equilibrium (isotherm) measurements with $\mathrm{H}_{2} \mathrm{O}$ on samples degassed exclusively at $383 \mathrm{~K}$ show the existence of reversibly adsorbed $\mathrm{H}_{2} \mathrm{O}$, with the highest amount adsorbed for the palagonite HWMK919 (Figure 6). In addition to the (remaining) strongly bonded $\mathrm{H}_{2} \mathrm{O}$ of about 10 wt.\%, the "total" $\mathrm{H}_{2} \mathrm{O}$ in $\mathrm{HWMK} 919$ amounts to $12.5 \mathrm{wt} . \%$ at $255 \mathrm{~K}$ and $0.001 \mathrm{mbar}$ (Figure 5). This is significantly more water compared with only $1-3 \mathrm{wt} . \%$ for nontronite or montmorillonite found previously under the same conditions (Jänchen et al., 2006).

\section{Conclusions}

These results show that fine-grained, phyllosilicate-poor palagonitic dust derived from 
palagonitic tephra HWMK919 can hold significantly more $\mathrm{H}_{2} \mathrm{O}$ than smectites under $\mathrm{p}\left(\mathrm{H}_{2} \mathrm{O}\right)$ and temperature conditions approaching those on the martian surface. Palagonitic dust is a geologically reasonable hydrated and hydroxylated phase on the surface of Mars, and its presence as dust may account, at least in part, for the observations of heterogeneously distributed elevated concentrations of water-equivalent $\mathrm{H}$ near the martian surface as detected by Mars Odyssey and the $3-\mu \mathrm{m}$ absorption band as seen by OMEGA and CRISM at the martian surface for the entire planet.

\section{Acknowledgements}

Support by the International Space Science Institute Bern, Switzerland, is acknowledged. DB gratefully acknowledges support by the NASA Mars Fundamental Research Program. RVM acknowledges support of the NASA Mars Exploration Rover Project, the NASA Mars Reconnaisance Orbiter CRISM Program, the NASA CRISM-OMEGA Collaboration, and the NASA Johnson Space Center. 


\section{References}

Bibring, J-P., Langevin, Y., Gendrine, A., Gondet, B., Poulet, F., Berté, M., Soufflot, A., Arvidson, R., Mangold, N., Mustard, J., Drossart, P., and the OMEGA team, 2005. Mars surface diversity as revealed by the OMEGA/Mars Express observations. Science 307, $1576-1581$.

D. L. Bish, J. W. Carey, D. T. Vaniman, S. J. Chipera (2003) Stability of hydrous minerals on the martian surface. Icarus, 164, 96-103.

Boynton, W.V., Feldman, W.C., Mitrofanov, I.G., Evans, L.G., Reedy, R.C., Squyres, S.W., Starr, R., Trombka, J.I., D’uston, C., Arnold, J.R., Englert, P.A.J., Metzger, A.E., Wänke,H., Brückner, J., Drake, D.M., Shinohara, C., Fellows, C., Hamara, D.K., Harshaman, K., Kerry, K., Turner, C., Ward, M., Barthe, H., Fuller, K.R., Storms, S.A., Thornton, G.W., Longmire, J.L., Litvak, M.L., Ton'chev, A.K., 2004. The Mars Odyssey gamma-ray spectrometer instrument suite. Space Sci. Res. 110, 37-83.

Chipera, S. J., Carey, J. W., Bish, D. L., 1997. Controlled-Humidity XRD Analyses: Application to the Study of Smectite Expansion/Contraction. In: Advances in X-ray Analysis, 39, J. Gilfrich et al. (Eds.), Plenum Press, New York, pp.713-722.

De Boer, J.B., Linsen, B.G., van der Plas, Th., Zondervan, G.J., 1965. Studies on pore systems in catalysis, VII. Description of the pore dimensions of carbon blacks by the $t$ method, J. Catal., 4, 649-653.

Fanale, F. F., Cannon, W.A., 1978. Mars: The role of the regolith in determining atmospheric pressure and the atmosphere's response to insolation changes, J. Geophys. Res., 83, 2321- 
2325.

Feldmann W.C., Prettyman, T.H., Maurice, S., Plaut, J.J., Bish, D.L., Vaniman, D.T., Mellon, M.T., Metzger, A.E., Squyres, S.W., Karunatillake, S., Boynton, W.V., Elphic, R.C., Funsten, H.O., Lawrence, D.J., Tokar, R.L., 2004. Global distribution of near-surface hydrogen on Mars. J. Geophys. Res. 109, E 09006, doi:10.1029/2003JE002160.

Hamayoon, K., Naoto, M., Teruo, H., 2006. Adsorption of water on nano-ball allophane. Clay Sci. 12, 261-266.

Jänchen, J., Bish, D.L., Möhlmann, D.T.F., Stach, H., 2006. Investigation of the water sorption properties of Mars-relevant micro- and mesoporous minerals. Icarus 180, 353358.

Jänchen, J., Möhlmann, D.T.F., Stach, H., 2007. Water and carbon dioxide sorption properties of natural zeolites and clay minerals at martian surface temperature and pressure conditions. Stud. Surf. Sci. Catal. 170, 2116-2121.

Jouglet, D., Poulet, F., Milliken, R.E., Mustard, J.F., Bibring, J.-P., Langevin, Y., Gondet, B., Gomez, C., 2007. Hydration state of the Martian surface as seen by Mars Express OMEGA: 1. Analysis of the $3 \mu \mathrm{m}$ hydration feature. J. Geophys. Res. 112, E08S06, doi: 10.1029/2006JE002846.

Lemmon, M. T., Wolff, M.J., Smith, M.D., Clancy, R.T., Banfield, D., Landis, G.A., Ghosh, A., Smith, P.H., Spanovich, N., Whitney, B., Whelley, P., Greeley, R., Thompson, S., 
Bell III, J.F., Squyres, S.W., 2004. Atmospheric imaging results from the Mars Exploration Rovers: Spirit and Opportunity, Science, 306, 1753-1756.

Markiewicz, W. J., Sablotny, R.M., Keller, H.U., Thomas, N., Titov, D., Smith, P., 1999. Optical properties of the Martian aerosols derived from Imager for Mars Pathfinder midday sky brightness data, J. Geophys. Res., 104, 9009-9017.

Milliken, R. E., J. F. Mustard, F. Poulet, D. Jouglet, J.-P. Bibring, B. Gondet, and Y. Langevin (2007), Hydration state of the Martian surface as seen by Mars Express OMEGA: 2. $\mathrm{H}_{2} \mathrm{O}$ content of the surface, J. Geophys. Res., 112, E08S07, doi:10.1029/2006JE002853.

Möhlmann, D.T.F., 2004. Water in the upper martian surface at mid- and low-latitudes: presence state, and consequences. Icarus168, 318-323.

Morris, R. V., Golden, D.C., Bell III, J.F., Shelfer, T.D., Scheinost, A.C., Hinman, N.W., Furniss, G., Mertzman, S.A., Bishop, J.L., Ming, D.W., Allen, C.C., Britt, D.T., 2000. Mineralogy, composition, and alteration of Mars Pathfinder rocks and soils: Evidence from multispectral, elemental, and magnetic data on terrestrial analogue, SNC meteorite, and Pathfinder samples. J. Geophys. Res. 105, 1757-1817.

Morris, R.V., Golden, D.C., Ming, D.W., Shefler, T.D., Jørgensen, L.C., Bell III, J.F., Graff, T.G., Mertzman, S.A., 2001. Phyllosilicate-poor palagonitic dust from Mauna Kea Volcano (Hawaii): A mineralogical analogue for magnetic martian dust. J. Geophys. Res. $106,5057-5083$. 
Mustard, J. F., S. L. Murchie, S. M. Pelkey, B. L. Ehlmann, R. E. Milliken, J. A. Grant, J.-P. Bibring, F. Poulet, J. Bishop, E. N. Dobrea, L. Roach, F. Seelos, R. E. Arvidson, S. Wiseman, R. Green, C. Hash, D. Humm, E. Malaret, J. A. McGovern, K. Seelos, T. Clancy, R. Clark, D. Des Marais, N. Izenberg, A. Knudson, Y. Langevin, T. Martin, P. McGuire, R. Morris, M. Robinson, T. Roush, M. Smith, G. Swayze, H. Taylor, T. Titus, and M. Wolff (2008), Hydrated silicated minerals on Mars observed by the Mars Reconnaissance Orbiter CRISM instrument, Nature, doi:10.1038/nature07097, 305-309.

Poulet, F. Bibring, J.-P., Mustard, J.F., Gendrine, A., Mangold, N., Langevin, Y., Arvidson, R.E., Gondet, B., Gomez, C., the OMEGA Team, 2005. Phyllosilicates on Mars and implications for early martian climate. Nature 438, 623-627.

Yen, A. S., Murra,y, B.C., Rossmann, G.R., 1998. Water content of the Martian soil: Laboratory simulations of reflectance spectra, J. Geophys. Res., 103, 11,125-11,133.

Zent, A. P., Fanale, F.P., Postawko, S.E., 1987. Carbon dioxide: Adsorption on palagonite and partitioning in the Martian regolith, Icarus, 71, 241-249.

Zent, A. P., Howard, D.J., Quinn, R.C., 2001. $\mathrm{H}_{2} \mathrm{O}$ adsorption on smectites: Application to the diurnal variation of $\mathrm{H}_{2} \mathrm{O}$ in the Martian atmosphere, J. Geophys. Res., 106, 14,667$14,674$.

Zent, A. P., Quinn, R.C., 1997. Measurement of $\mathrm{H}_{2} \mathrm{O}$ adsorption under Mars-like conditions: Effects of adsorbent heterogeneity, J. Geophys. Res., 102, 9085-9095. 


\section{Tables}

Table 1

Characterization data for palagonitic dust and smectite samples.

\begin{tabular}{lccccc}
\hline & $\begin{array}{c}\text { Specific } \\
\text { surface area } \\
\left(\mathrm{m}^{2} / \mathrm{g}\right)\end{array}$ & $\begin{array}{c}\text { Mesopore } \\
\text { diameter } \\
(\mathrm{nm})\end{array}$ & $\begin{array}{c}\text { Micropore } \\
\text { volume }^{\mathrm{a}} \\
\left(\mathrm{cm}^{3} / \mathrm{g}\right)\end{array}$ & $\begin{array}{c}\text { Particle } \\
\text { diameter } \\
(\mu \mathrm{m})\end{array}$ & $\begin{array}{c}\text { Mass } \\
\text { loss } \\
(\mathrm{g} / \mathrm{g})\end{array}$ \\
HWMK919 $<5 \mu \mathrm{m}$ & $203 \pm 1$ & 4 & 0.05 & $<5^{\mathrm{b}}$ & $0.325 \pm 0.01$ \\
Nontronite, NG-1 & $66 \pm 2$ & 3.8 & 0 & $9^{\mathrm{c}}$ & $0.19 \pm 0.01$ \\
Montmorillonite, STx-1 & $74 \pm 2$ & 4 & 0 & $5^{\mathrm{c}}$ & $0.17 \pm 0.01$ \\
\hline
\end{tabular}

${ }^{a}$ Micropore volume for $\mathrm{N}_{2}$ adsorption according to t-method, see text

${ }^{\mathrm{b}}$ From Morris et al. (2001).

${ }^{\mathrm{c}}$ From $\mathrm{Hg}$ intrusion.

${ }^{\mathrm{d}} \mathrm{TG}$ mass loss after equilibration at $\mathrm{H}_{2} \mathrm{O} \mathrm{p} / \mathrm{p}_{0}=0.3$. 


\section{Figure captions}

Figure 1. Nitrogen adsorption (open symbols) and desorption (filled symbols) isotherms at 77 K for $<5 \mu \mathrm{m}$ HWMK919 (diamond), STx-1 (squares), and NG-1 (triangles); adsorbed amount, a, in $\mathrm{cm}^{3}$ nitrogen gas, stp.

Figure 2. Scanning electron micrograph of $<5 \mu \mathrm{m}$ HWMK919.

Figure 3. TG profiles for STx-1, NG-1, and HWMK919 (from top to bottom on the right).

Figure 4. Mass losses in $\mathrm{g} / \mathrm{g} / \mathrm{K}$ (DTG) of $<5 \mu \mathrm{m}$ HWMK919 (squares), NG-1 (triangles), and STx-1 (circles).

Figure 5. $\mathrm{H}_{2} \mathrm{O}$ adsorption (open symbols) and desorption (closed symbols) isotherms for HWMK919<5 $<$ m at 255 (circles), 273 (triangles), 293 (diamonds), and $313 \mathrm{~K}$ (inverted triangles), adsorbed amount, a, in $\mathrm{g} \mathrm{H}_{2} \mathrm{O} / \mathrm{g} \mathrm{HWMK} 919$, the dashed line indicates the $\mathrm{H}_{2} \mathrm{O}$ vapor pressure on the martian surface.

Figure 6. $\mathrm{H}_{2} \mathrm{O}$ adsorption/desorption isotherms for $<5 \mu \mathrm{m}$ HWMK919 (triangles) and NG-1 (circles) at $293 \mathrm{~K}$ after degassing at $383 \mathrm{~K}$ in high vacuum, filled symbols denote desorption, adsorbed amount, a, in $\mathrm{g} \mathrm{H}_{2} \mathrm{O} / \mathrm{g}$ mineral.

Figure 7. $\mathrm{CO}_{2}$ adsorption (open symbols) and desorption (closed symbols) isotherms for HWMK919 <5 $\mu \mathrm{m}$, at 196, 273, and $293 \mathrm{~K}$ (from top to bottom), adsorbed amount, a, in $\mathrm{g}$ $\mathrm{CO}_{2} / \mathrm{g}$ HWMK919. 
Figure 8. $\mathrm{CO}_{2}$ isotherms for $<5 \mu \mathrm{m}$ HWMK919 (filled symbols) and NG-1 (open symbols) at 196 (triangles), 273 (squares), and $293 \mathrm{~K}$ (circles), adsorbed amount, a, in $\mathrm{cm}^{3}$ liquid $\mathrm{CO}_{2} / \mathrm{g}$ mineral. 


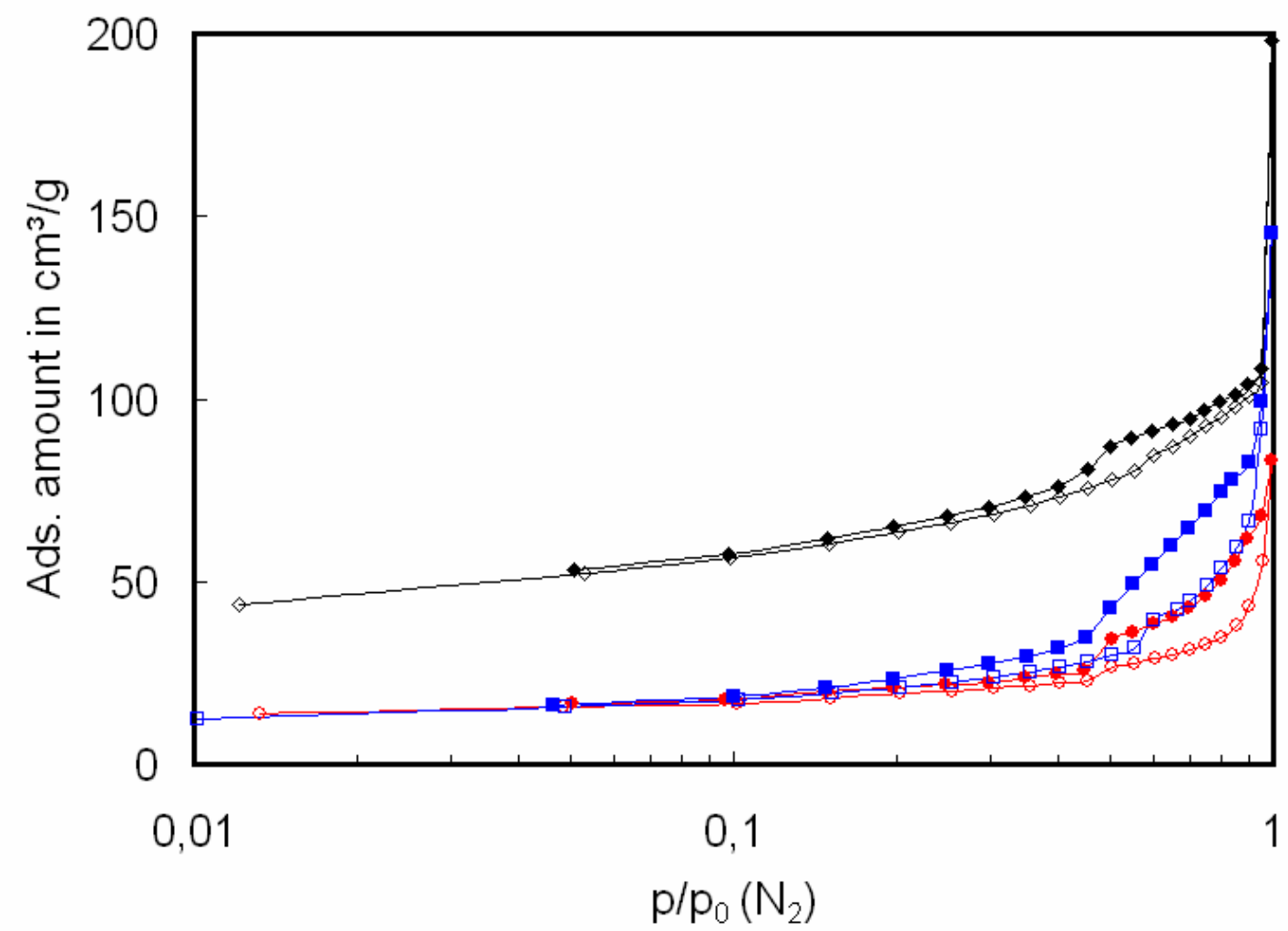

Figure 1. Nitrogen adsorption (open symbols) and desorption (filled symbols) isotherms at 77 K of HWMK919 <5 $\mu \mathrm{m}$ (diamond), STx (squares), and NG-1 (triangles); adsorbed amount, a, in $\mathrm{cm}^{3}$ nitrogen gas, stp.

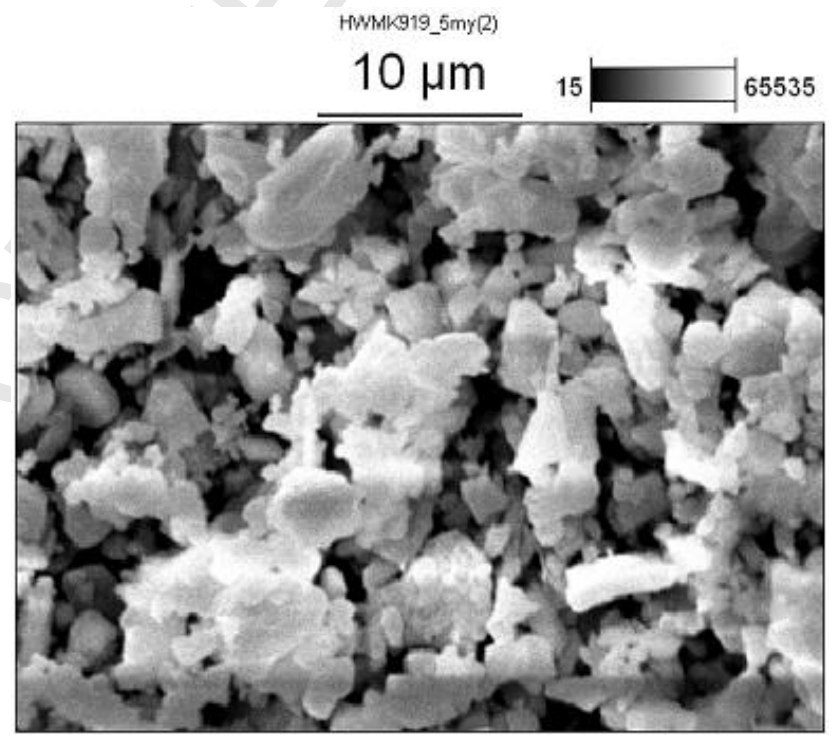

Figure 2. Scanning electron micrograph of $<5 \mu \mathrm{m}$ palagonitic dust HWMK919. 


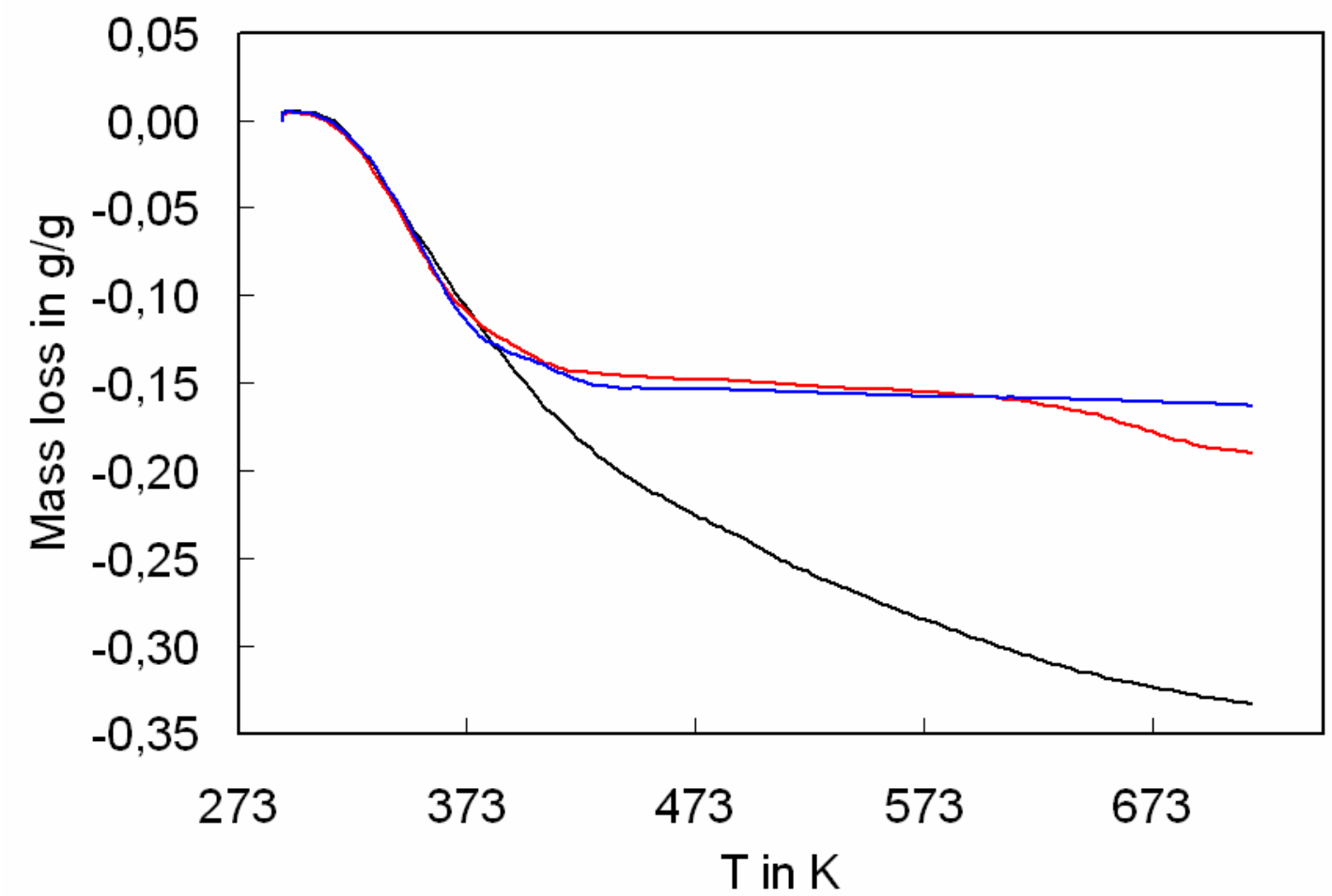

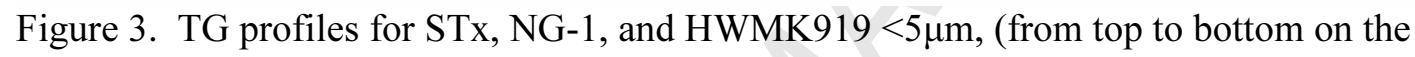
right)

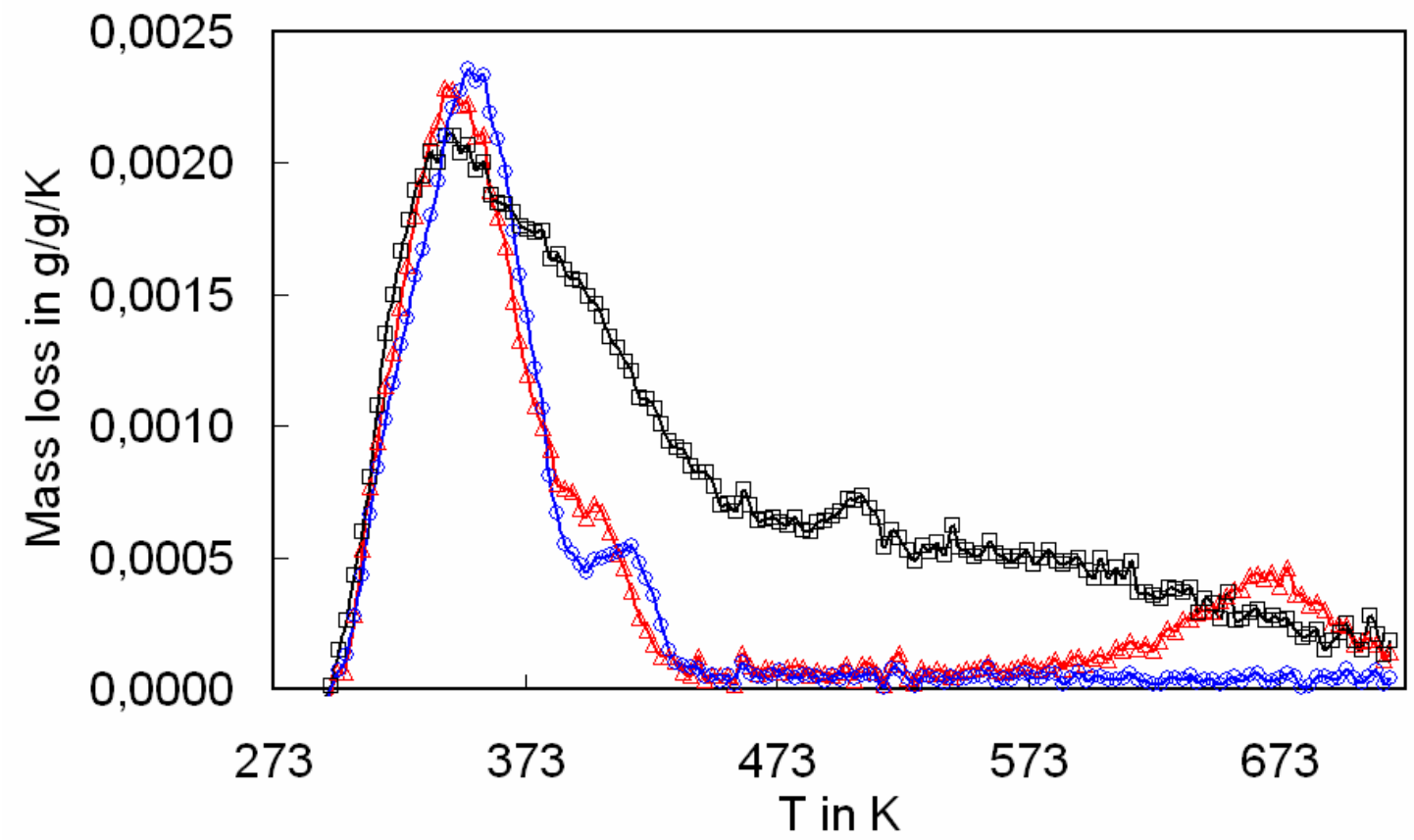

Figure 4. Mass losses in $\mathrm{g} / \mathrm{g} / \mathrm{K}$ (DTG) of HWMK919 $<5 \mu \mathrm{m}$ (squares), NG-1 (triangles) and STx (circles). 


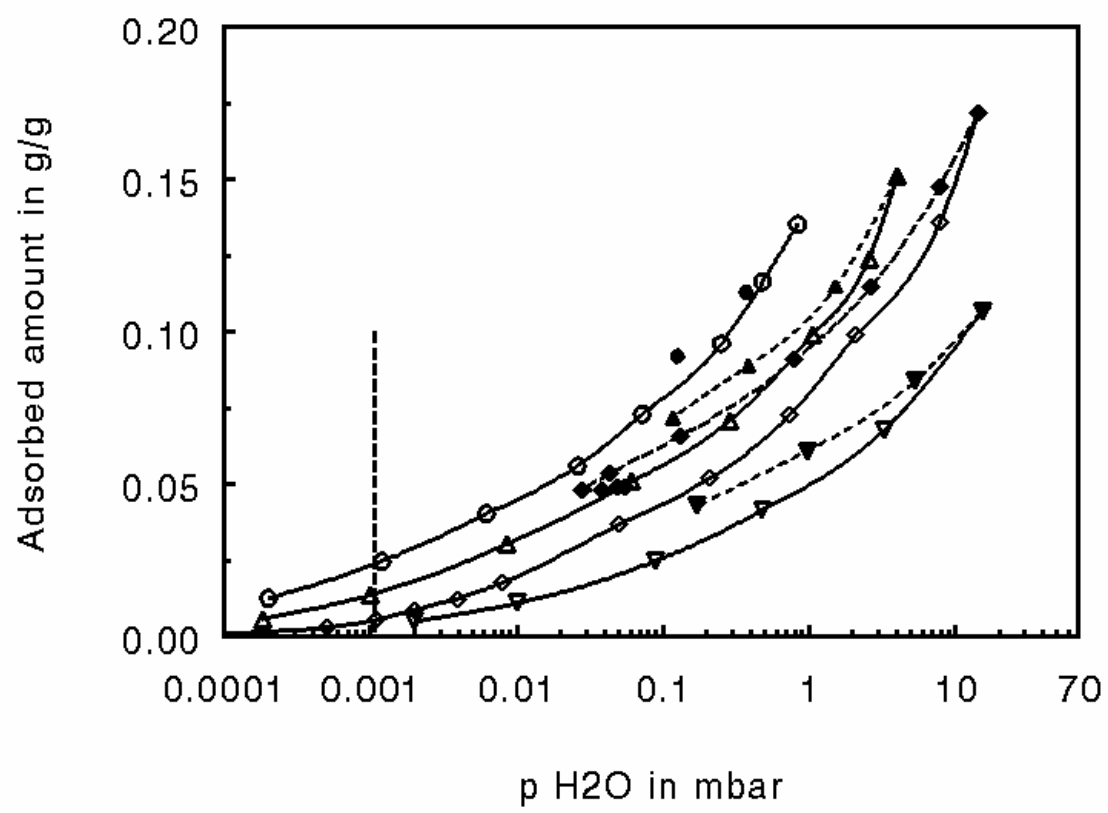

Figure 5. $\mathrm{H}_{2} \mathrm{O}$ adsorption (open symbols) and desorption (closed symbols) isotherms for HWMK $919<5 \mu \mathrm{m}$ at 255 (circles), 273 (triangles), 293 (diamonds), and $313 \mathrm{~K}$ (inverted triangles), adsorbed amount, a, in $\mathrm{g} \mathrm{H}_{2} \mathrm{O} / \mathrm{g}$ HWMK919, the dashed line indicates the $\mathrm{H}_{2} \mathrm{O}$ vapor pressure on the martian surface.

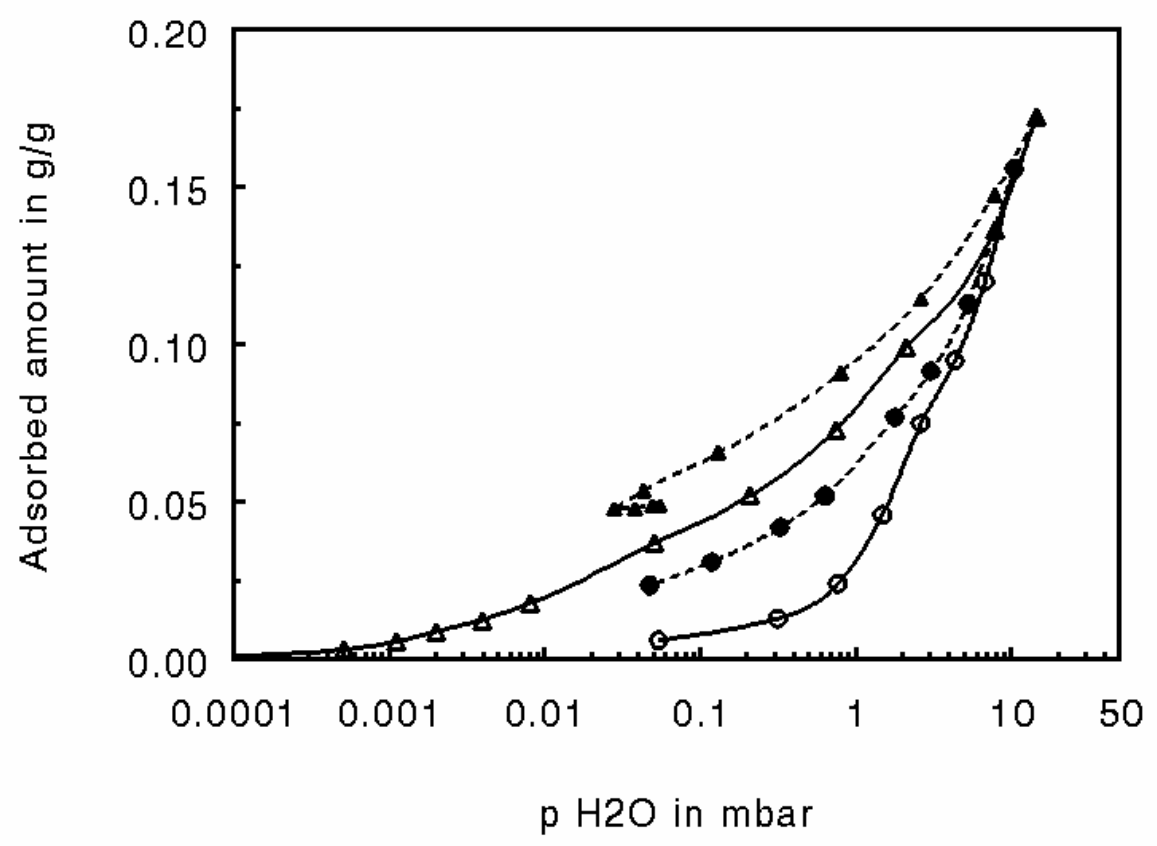

Figure 6. $\mathrm{H}_{2} \mathrm{O}$ adsorption/desorption isotherms for $<5 \mu \mathrm{m}$ HWMK919 (triangles) and NG-1 (circles) at $293 \mathrm{~K}$ after degassing at $383 \mathrm{~K}$ in high vacuum, filled symbols denote desorption, adsorbed amount, a, in $\mathrm{g}_{2} \mathrm{O} / \mathrm{g}$ mineral 


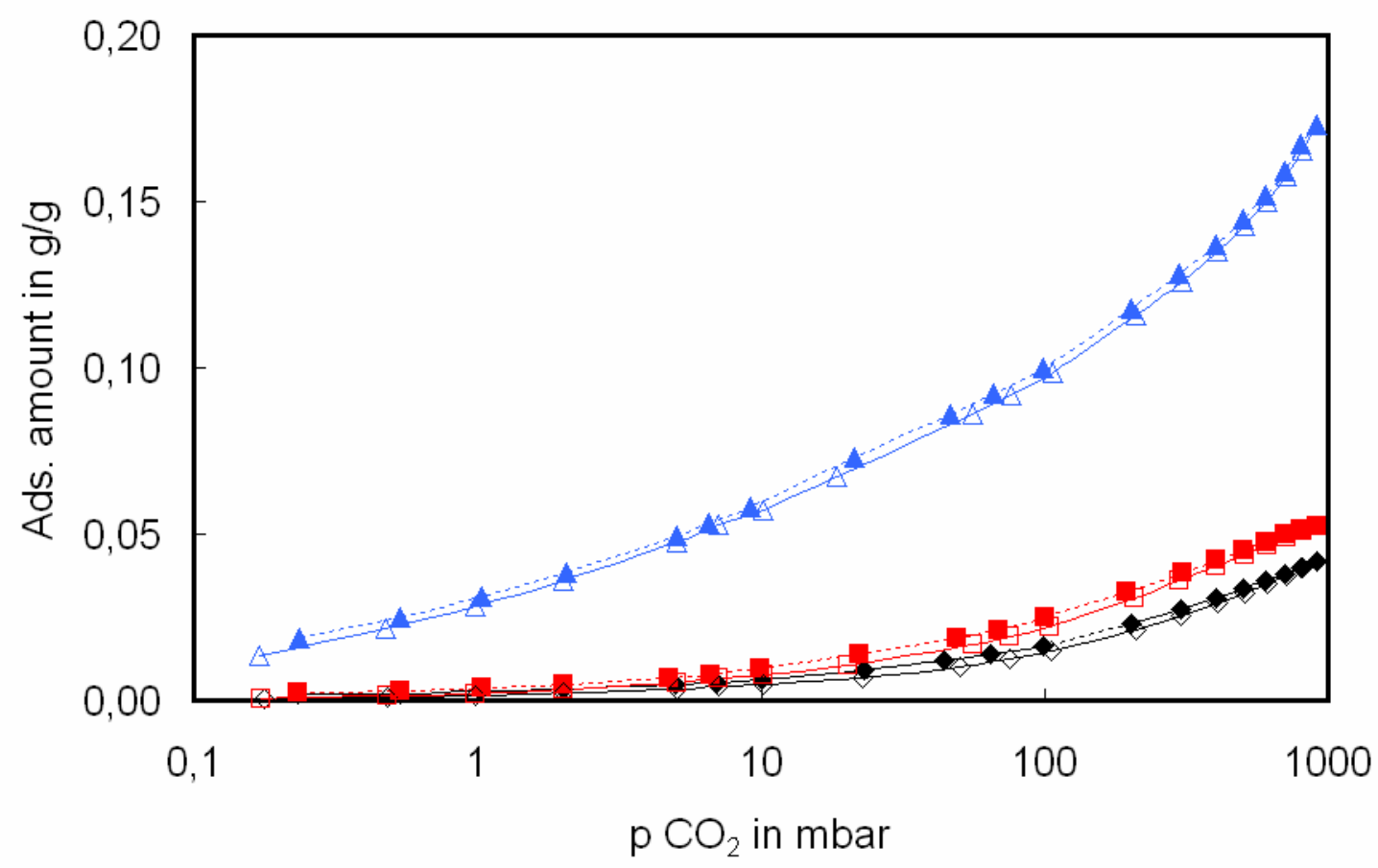

Figure 7. $\mathrm{CO}_{2}$ adsorption (open symbols) and desorption (closed symbols) isotherms for HWMK919 $<5 \mu \mathrm{m}$, at 196, 273, and $293 \mathrm{~K}$ (from top to bottom), adsorbed amount, a, in $\mathrm{g}$ $\mathrm{CO}_{2} / \mathrm{g}$ HWMK919.

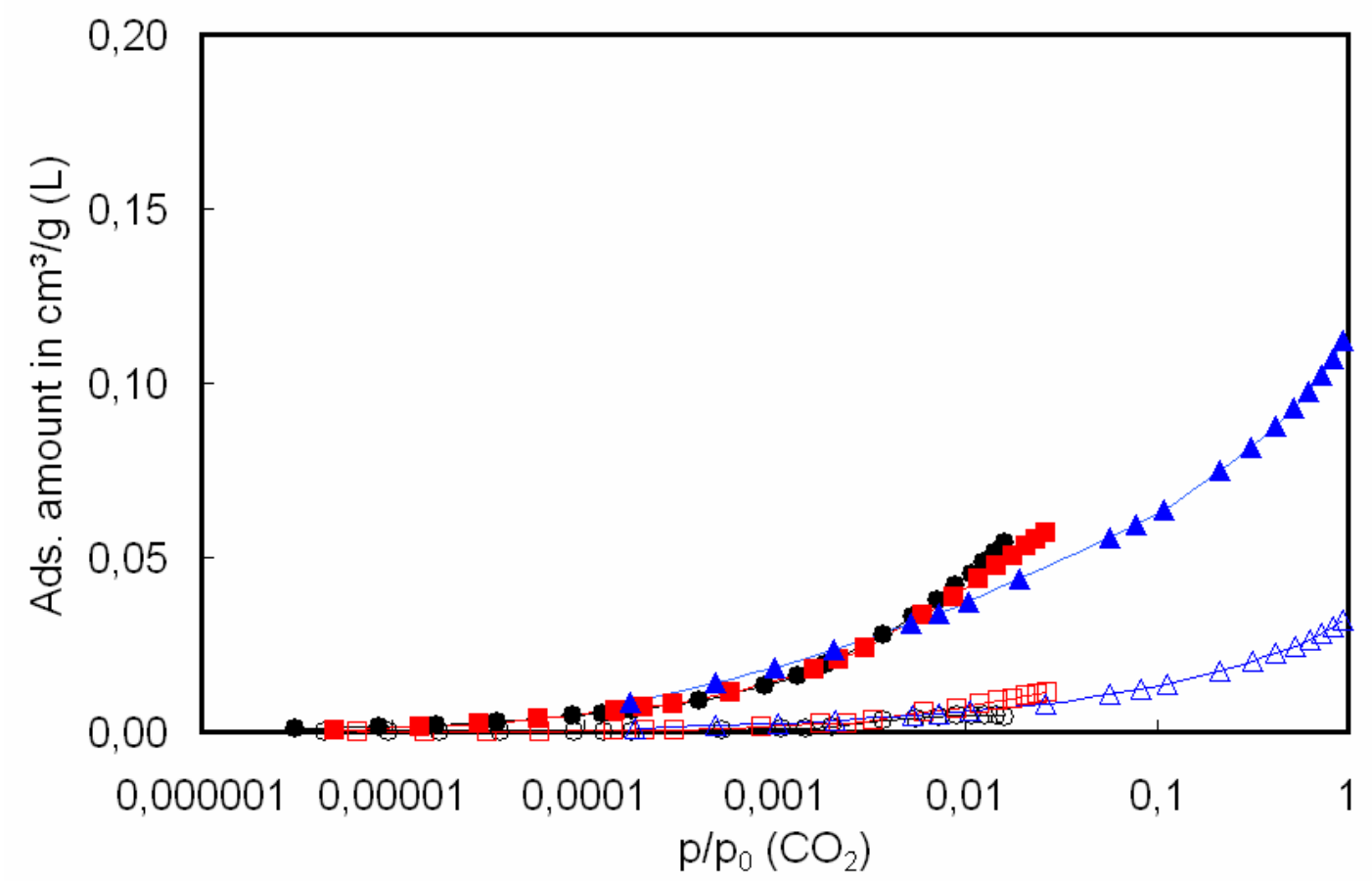

Figure 8. $\mathrm{CO}_{2}$ isotherms for $<5 \mu \mathrm{m}$ HWMK919 (filled symbols) and NG-1 (open symbols) at 196 (triangles), 273 (squares), and $293 \mathrm{~K}$ (circles), adsorbed amount, a, in $\mathrm{cm}^{3}$ liquid $\mathrm{CO}_{2} / \mathrm{g}$ mineral. 